\title{
＜面内・面外方向に組み合わせたサンドイッチ構造物の圧潰特性に関する特性＞
}

\section{$<$ Study on Crushing Characteristics of Sandwich Structure Alternately Combined With In-plane and Out-of-plane Directions>}

\author{
$<$ 岡田光・東京理科大学工学部 $>$ \\ $<$ Kou OKADA, Tokyo University of Science $>$ \\ <陳玳㹸・東京理科大学工学部> \\ $<$ Dai-Heng CHEN, Tokyo University of Science $>$ \\ $<$ 尾崎伸吾・横浜国立大学工学部研究院> \\ $<$ Shingo OZAKI, Yokohama National University>
}

Key Words: < Honeycomb, Sandwich Structure, Plasticity, Crush, FEM>

\begin{abstract}
高速道路等における髣衝材として面内方向ハニカム・面外方向ハニカムを組み合わせたサンド イッチハニカム構造物が、用いられている. 緩衝材として、様々な衝突条件に対応することが 要求されるため、本研究では、面内方向ハニカム - 面外方向ハニカムの形状、セルの配列等が 圧潰特性にどのように変化をもたらすのかを検討した．圧潰特性はハニカム形状のパラメータ $t_{1} / l$ に依存し、このパラメータを変化させることにより圧潰特性をある程度調整することが出来 るということが確認された.
\end{abstract}

\section{1. 緒言}

高速道路等における緩衝材として、ハニカム材を様々な方 向に組み合わせたサンドイッチ構造物が用いられている. 高速道路に設置する緩衝材として、様々な衝突条件（衝突す る車の形状・重量・速度など)に対応することが要求される.

\section{2. 解析方法及び条件}

本研究では、図 1 に示寸ような面内力向八二カムと面外方 向ハニカムを組み合わせたサンドイッチモデル（図中では、 面ない力向ハニカムが下側）を用いて、有限要素法用ソフト MSC.Dytran を用いて動的弾塑性解析を行う。具体的には、 モデル上側から衝突速度 $\mathrm{V}_{0}$ 、質量 $\mathrm{M}$ を持つ移動岡体板または 球体を衝突させることで圧潰させる．また、境界・接触条件 は、下端を完全固定、八二カムとパネル間には摩擦を考慮し、 摩擦係数 $\mu=0.3$ とする. 供試材料としてハニカム、パネルと もアルミニウム合金を想定し、応力ーひずみ関係は二直線硬 化則で近似出来るものとする。ここに、八二カム厚 $t_{1}$ は一般 的な生産方法を考慮して、1組の向かい合らセル壁の厚さを 他の 2 倍としている。なお、本研究では、応力は剛体下の反 力を図 2 の長方形の面積で割ったものと定義して検討を進め る。
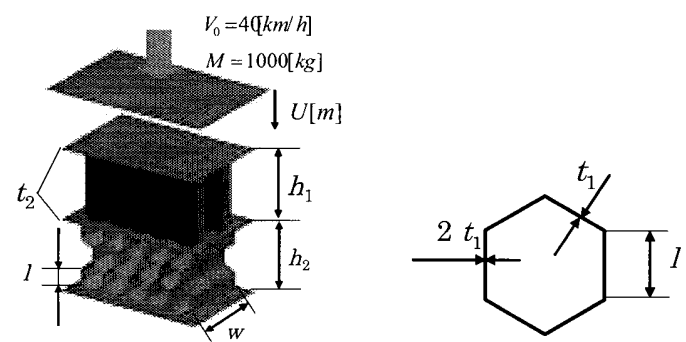

Fig. 1:Basic models of sandwich structures combination :Model A

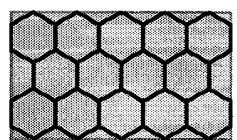

Fig.2:Area for estimation of compressive stress

\section{3. 解析結果及び検討}

\section{1 平板による基本的圧潰挙動}

面内方向、面外方向八二カムを便宜上それぞ北 単体横”、 “単体縦”と呼び、図 1 のような複合モデルを“組み合わせ” と呼ぶことにする，組み合わせの圧潰は基本的に“単体横” 側から圧潰し、緻密化による応力上昇後に単体縦側が圧潰す る. 各単体と組み合わせの剛体移動量と圧縮応力の関係を図 3 に示す.この時、“単体横”の応力が単体縦の平均応力を超 える位置に単体縦のグラフを移動させることで両者を比較 出来、ほぼ一致することが分かる。これにより、“単体縦”。 “単体横”モデルから“組み合わせ”の挙動を予測すること が可能である.

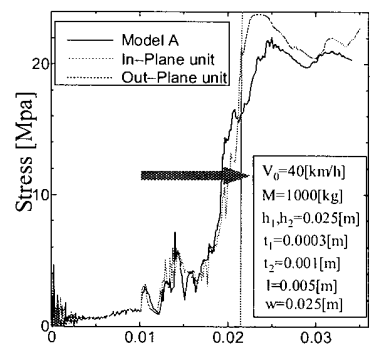

Fig.3 Relation of U and Stress frot Model A and Unit model

\section{2 箔厚変化の影響}

岡体移動量と圧縮応力の関係から、“単体横”側の平均応 力 $\sigma_{I n}$ 、“単体縦”側の平均応力 $\sigma_{O u t}$ を定義し、図 4 に縦軸 に $\sigma_{I n} / \sigma_{O u t}$ 横軸に $t_{1} / l$ としたグラフを掲載する.なお、図 4 左は“単体横”のみ変化させた場合、右図は“単体縦”のを 変化させた場合であり、赤いプロットはセル厚を変化させた 場合、青いプロットはセル長さを変化させた場合である. 図 より、単体縦に対する” 単体横”の平均応力の比をそれぞれ の箔厚の大きさを変更することで調整できることが分かる. したがって、様々なモデルの材料特性および幾何条件に対す るそれぞれの単体モデルの平均応力の理論式を用いること によって、圧縮応力-変位関係が調整可能になる. 

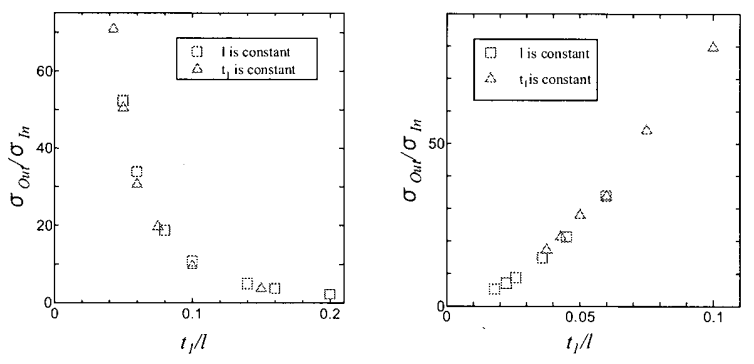

Fig.4: Relation of $t_{1} / l$ and $\sigma_{l n} / \sigma_{\text {Out }}$

\section{3 剛体形状への依存性}

ここまでは、移動剛体を平板として検討してきたが、以下 ではモデル B として、図 5(a)のような球状剛体による圧潰挙 動について検討する。平板の場合と球の場合では“単体横” 側ではほぼ同じ挙動を示すが、それ以降、単体縦側において 接触面積が小さくなるため圧縮応力は低くなることが見て 取れる (図 $5(\mathrm{~b})$ ). 平板における単体縦側の平均応力 $\sigma_{\text {Out }}$ (plate) 基準とし、球における単体横側の平均応力 $\sigma_{\text {Out }}($ ball $)$ の比 $\sigma_{o u t}($ ball $) / \sigma_{\text {out }}$ (plate) をとったものを図 5(c) に載せる.これより半径 $\mathrm{r}$ を増加させるに従い応力比は 1 に 近づいていき $\mathrm{r}=0.075[\mathrm{~m}]$ においてはほぼ平板と等しい挙動を 示すことがわかる.

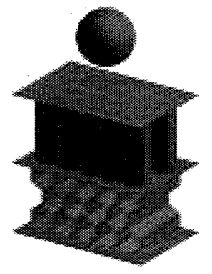

(a)

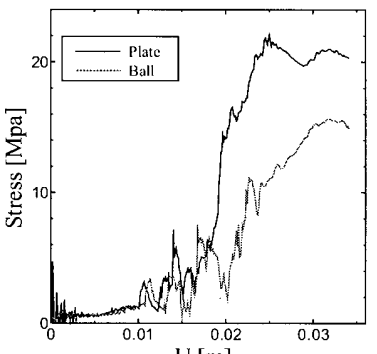

(b) ${ }^{[\mathrm{m}]}$

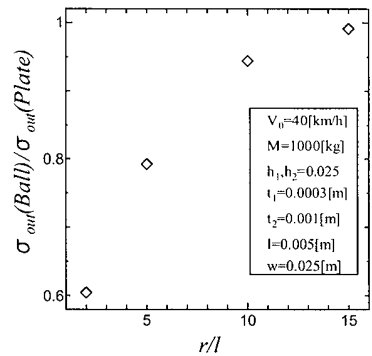

(c)

Fig.5: Influences of rigid body shape on compressive stress

(a) Model B (b) Relation of U and Stress for Model B

(c) Relation of stress with radius

\section{4 セルの配列をずらしたモデルについて}

“単体縦”のモデルの配列をずらして組み合わせたモデ ルが存在する。このモデルを Crush Cushion Model と呼ぶ. 基本的なモデル形状として図 6(a)のように上下のセルの配 列を丁度セルの半分ずらした Model を Crush cushion Model の基本形状とした。この際、八ニカムの形状及び材料定数は 今までと同じ条件を用いている．板剛体の衝突に関しては応 力にはそこまで大きな影響がでるとは言えないが、Crush Cushion Model の方が多少低い忘力值を示している.

Model Cとしてセルが重なった状態（Normal Model）から 少しずつずらして行き、それによる変化を観察した．Node 番号に対応してモデル名を(0)、(1)、(2)…(5)とつける.つまり モデル(1) Normal Model であり、モデル(5)は Crush Cushion Model である. 図 7 右図に各モデルと平均応力の関係を示す. 図 7 右図をみると最も高い平均応力で圧潰するのは“ (0)”
（Normal Mode）であり、安定した圧潰特性を示しているこ とが分かる。それ以外のモデルにおいては、平均応力はほぼ 変わらない值を示した.

図 8 に Model C の変形の様子を示寸。しかし、変形様子と見 比べてみるど (1)”のモデルは右側に大きくバランスを崩し てしまっている.他のモデルに関しては、変形するセルにば らつきがあるが、圧潰は安定して垂直に起こっている.

以上のことから微少量配列がずれることが不安定な圧潰 に繋がるということが言える. Crush Cushion Mode1 のよう にある程度セルの配列をずらしておけば、作成する過程にお いて配列がずれてしまった場合でも応力・圧潰等にほとんど 影響を与えないといえる。

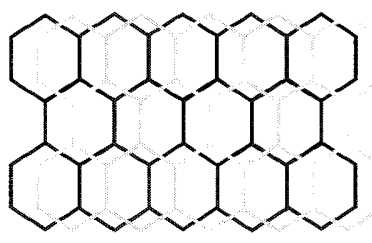

(a)

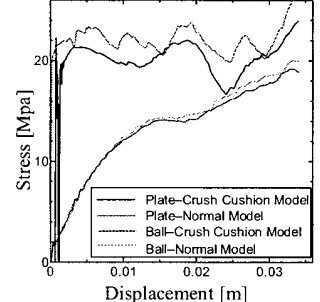

(b)
Fig.6:Crush Cushion Model (a)Crush Cushion Model (b)Relation of Displacement to Stress for Various model shapes and load condition

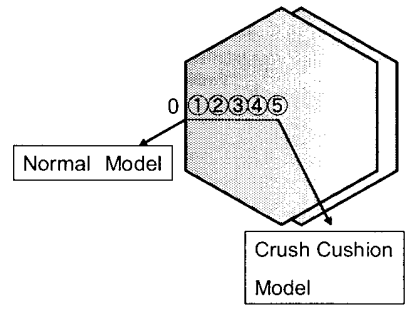

(a)

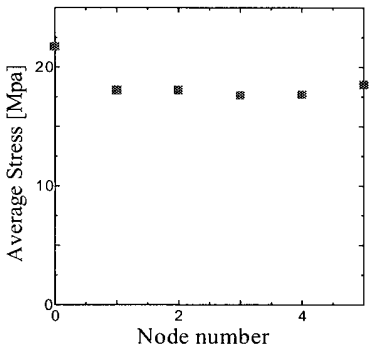

(b)
Fig.7: Influence of node number (a)Model C

(b)Comparison of Average stress for Model C

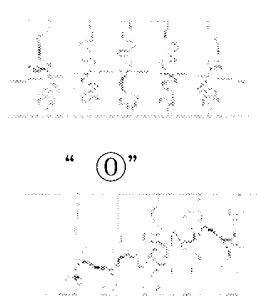

“ (3)"

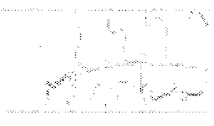

“ (1)"

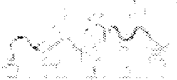

“ (4)"

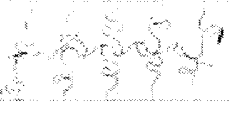

“ (2)"
Fig.8: Comparison of deformed shape

\section{4. 結言}

1. 単体モデルから組み合わせモデルの圧潰挙動を予測する ことが可能である。

2. 様々なモデルの材料特性および幾何条件（セル厚 t、セ ル長さ 1）に対するそれぞれの単体モデルの平均応力の 理論式を用いることによって、圧縮応力一変位関係が調 整可能になり、理想的な吸収エネルギ部材としての設計 が可能になる.

3. 球剛体の衝突において、半径 $\mathrm{r}$ を増加させるに従い平板 の挙動に近づいていく.

4. 組み合わせ八ニカム構造物製造工程に置き、上下のセル の配列に䛊差が出てしまうことにより圧潰が不安定に なる.この問題を解決するために上下のセルの配列をあ らかじめずらしたモデルにすることが有効である. 